\section{they do, damned if they don't...}

It's crunch time for agribiotech in Britain, as politicians rule on the planting of commercial transgenic crops. The world is watching,
says Jim Giles.

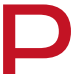
oliticians don't often evoke pity. But it's hard not to feel some sympathy for the British ministers who must, over the coming months, decide on whether to give the green light for the commercial cultivation of genetically modified (GM) crops. They're in a 'no-win' situation.

On the one hand, the government wants to support the biotech industry, which it sees as a key component of Britain's future economic competitiveness. It also wants to appease its closest ally, the United States, which is already fuming over Europe's reluctance to embrace transgenic agriculture. But surveys have shown that, for now at least, the British public doesn't want to see GM crops grown commercially. And with the government's popularity dipping in the wake of the war in Iraq, brazenly defying public opinion is not an attractive option. "The British government is in a difficult position," concludes Simon Barber of EuropaBio, a Brussels-based body that represents Europe's biotech industry.

The arguments over transgenic agriculture have been played out more vociferously in Britain than in perhaps any other country. This ensures that the government's decision will resonate beyond the shores of the British Isles, colouring the debate over transgenic agriculture both at the European level and beyond.

Ministers must wish that they could kick the problem into touch and return to it when the political climate is more favourable. But matters are now coming to a head, thanks in part to a timetable of the government's own making. In 1999, as arguments over GM crops raged in

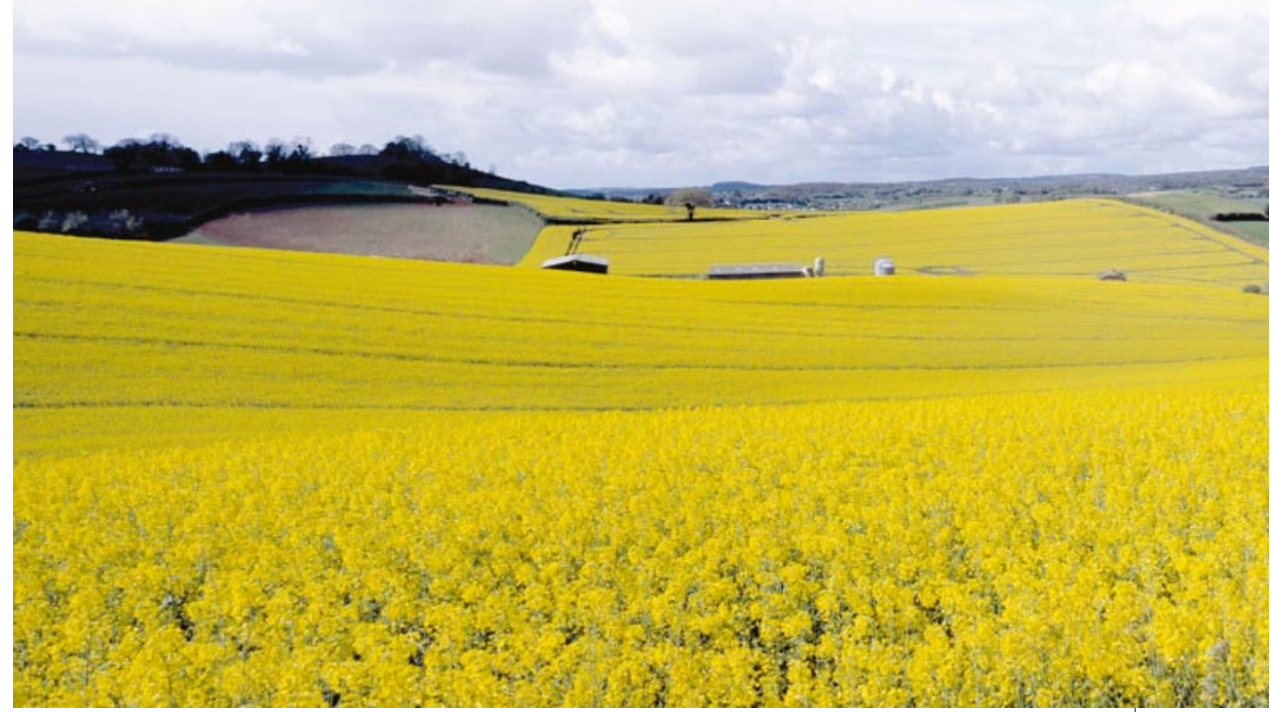

the media, the government announced that applications to begin commercial planting of herbicide-tolerant GM maize, oilseed rape (or canola) and beet would be put on hold, pending the results of 'farm-scale evaluations', taking several years, of the crops' impact on farmland biodiversity. Results from thesehuge experiments will be published this week.

\section{Ask the people}

But public concerns about GM agriculture run wider than the question of whether herbicide-tolerant crops will disrupt populations of weeds and invertebrates. There are anxieties about the safety of GM food, for example, and about whether transgenes will 'pollute' organic crops. So, over the past few months, the government has embarked upon an elaborate exercise in evaluation and public consultation. A scientific panel has reviewed the pros and cons of transgenic agriculture; Prime Minister Tony Blair's Strategy Unit has considered the economic case; and the 'GM

Nation?' debate, involving more than 600 meetings, has sampled public opinion.

For the government, it has been a sobering exercise. The scientific panel, while pointing out areas of uncertainty that need further research, voiced no fundamental objection to transgenic agriculture. But if Blair hoped that the public would warm to the idea of GM farming, he was mistaken the 'GM Nation?' debates revealed hostile attitudes towards the technology. Although the apparent depth of feeling will have been exaggerated by the presence of environmen- tal activists at the meetings, other opinion polls have found little support for the commercialization of GM crops. And economic specialists have advised the government that there is little to gain by pressing ahead while consumers remain so suspicious.

Sources in the biotech industry accept that transgenic crops will not be a money-spinner in Britain until consumer opposition softens, but they are desperate for the government to send out a positive message by approving the commercialization, in principle, of herbicidetolerant GM crops. Without such a move, they claim, investment and scientific talent will drift away to more favourable pastures.

Some senior plant-biotech researchers have already announced plans to leave Britain this year. "Public opposition has caused industry to bleed away, which reduces funding opportunities and options for the future employment of students," says Mark Tester of the University of Cambridge, who is shortly to join the Australian Centre for Plant Functional Genomics at the University of Adelaide. One company, Bayer CropScience of Hauxton, near Cambridge, suspended its field trials of GM crops late last month, complaining that its experimental plots could not be guaranteed protection from protesters intent on their destruction. Blocking or delaying the decision to approve transgenic crops for commercial use will exacerbate these trends. "It would send out a very negative signal," says Barber.

It would also widen the rift between the United States and Europe - something that Blair is anxious to avoid. The World Trade Organization is already considering a complaint brought by the United States against the European Union (EU) over its failure since 1998 to approve any new GM crop for 


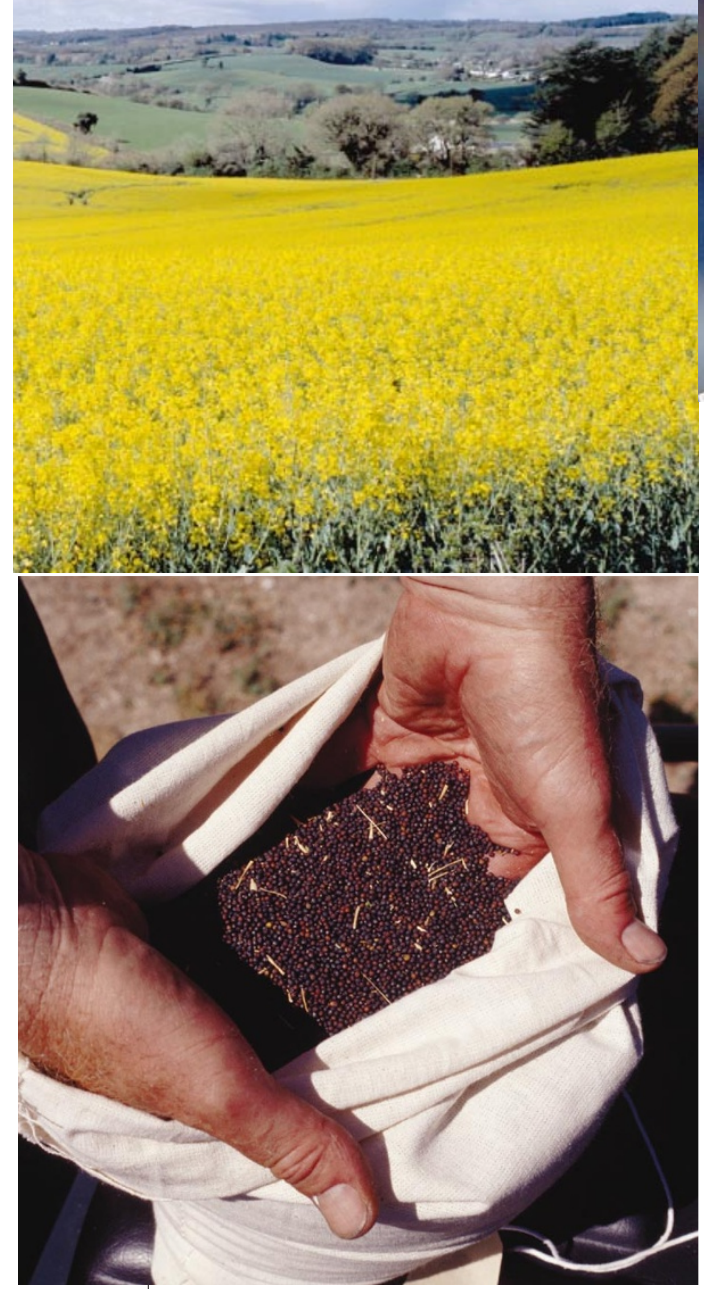

commercial planting or human consumption. Thanks to opposition from countries including Denmark, France, Greece, Italy and Luxembourg, some 20 pending applications have been left in limbo.

GM agriculture is not the only issue that splits the United States and Europe - the war in Iraq has also soured transatlantic relations. And as Blair calculates his political future, the two issues could become entwined. In Britain, doubts about the wisdom of invading Iraq are mounting, particularly in light of the death of David Kelly, a scientific expert at the Ministry of Defence. Kelly took his own life after being identified as the source of a $\mathrm{BBC}$ radio story alleging that the government had exaggerated intelligence on Iraq's weapons capability to win support for the war. The affair, now the subject of an independent inquiry, has dented public trust in the government. Against this

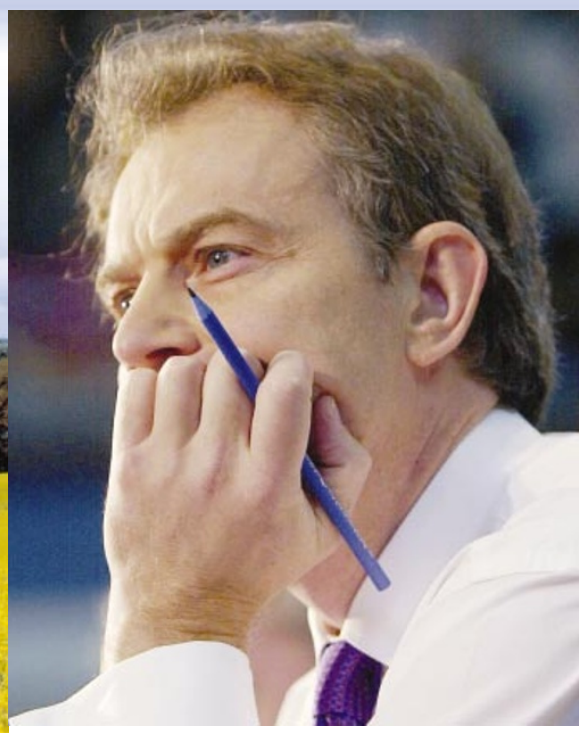

On trial: whatever the result of Britain's tests of transgenic oilseed rape (left and below left), the final decision will also be influenced by Tony Blair's desire to keep a sceptical public happy.

background, Blair will not want to be seen as disdainful of public opposition to GM crops.

The farm-scale evaluations could offer an escape route. If they suggest that GM herbicide-tolerant crops might damage the environment, biotech firms will have little basis for complaint if approval for commercial planting is denied or delayed. Some press reports have suggested that the farm-scale trials will indeed raise red flags against some of the tested crops. But with the scientists involved keeping the results under a strict embargo, the truth will only be unveiled this week.

\section{Stalling tactics}

If the farm-scale trials contain no showstoppers, the best bet for the government would be to delay the decision until public disquiet over Iraq and Kelly has subsided. The government has already pledged to refer the results of the farm-scale evaluations to an expert scientific panel, the Advisory Committee on Releases to the Environment. Awaiting its advice will probably delay things until January. A second set of results from the trials, based on winter planting of oilseed rape, is due out in the middle of next year, and could be used to stall a decision yet further.

But by then, the government's hand may have been forced by events at the European level. Following the drafting of strict new rules on labelling of GM produce, together with requirements that should allow transgenic ingredients to be traced from farm to fork, the stalled process of approving GM crops for growth and sale in the EU is expected to resume around the turn of the year.

Even if developments in Brussels mean that the British government has little choice but to sanction the commercial planting of GM herbicide-tolerant crops in principle, it might be able to placate public opinion in other ways. When the EU's provisions for tracing and labelling GM foods were agreed last July, member states were given the freedom to set their own 'coexistence' rules designed to minimize cross-pollination between GM and non-GM crops. "Tough legislation in this area would knock commercial planting on its head," says a senior figure in one environmental organization.

The Agriculture and Environment Biotechnology Commission, another government advisory body, is currently grappling with the issue of coexistence, and is due to report any day soon. Opponents of transgenic farming argue, for example, that fields used to grow GM crops should subsequently be kept free of non-GM varieties for several years; the biotech industry retorts that such measures would make transgenic crops uneconomical.

New laws on liability could also make commercial planting financially unattractive. Environmental groups point out that forcing agribiotech companies to take legal responsibility if transgenes spread to organic crops, or have unforeseen effects on biodiversity, could provide another way for the government to approve the crops while ensuring that they are unlikely to be grown.

The biotech industry, meanwhile, may prefer a compromise that makes commercialization contingent on stringent scientific monitoring, while setting limits on the total area that can be cultivated. It is unclear whether such limits would be allowed under EUlaw, but they would suit agribiotech firms in the short term - especially as consumer demand is so low.

The government's eventual strategy may depend on Blair's popularity in the coming months, which in turn rests on the report of the inquiry into Kelly's death. "If Blair comes out badly, he won't want to take risks," says one British expert in food and environmental policy. Blair might then try to show that he is in tune with public opinion by bringing in rules that effectively shelve the introduction of transgenic agriculture. "This is a political decision, not a scientific one," agrees Tester.

If these predictions are correct, it would be an odd end to a debate in which environmental groups and the agribiotech industry have invested enormous effort. It would also be demoralizing for researchers who have devoted the past four years to the farm-scale evaluations - not to mention everyone involved in this summer's huge evaluation and consultation exercise. But that's politics for you. Jim Giles is a reporter for Nature in London.

Farm-scale evaluations

www.defra.gov.uk/environment/gm/fse/ index.htm

Science review

www.gmsciencedebate.org.uk

Economic review

www.number-10.gov.uk/su/gm/index.htm

'GM Nation?' public debate

www.gmnation.org.uk 